\title{
MULTIPLE DISEASE RESISTANCE IN INTERGENERIC HYBRIDS
}

\author{
George Fedak ${ }^{1}$, Dawn Chi $^{1}$, Colin Hiebert ${ }^{2}$, \\ Tom Fetch ${ }^{2}$, Brent McCallum ${ }^{2}$, Allen Xue ${ }^{1}$, Wenguang Cao ${ }^{1}$ \\ ${ }^{1}$ Ottawa Research and Development Centre, \\ Agriculture and Agri-Food Canada, Ottawa, ON. K1A 0C6, Canada \\ ${ }^{2}$ Morden Research and Development Centre, \\ Agriculture and Agri-Food Canada, Morden MB. R6M 1Y5, Canada
}

https://doi.org/10.31734/agronomy2019.01.173

\begin{abstract}
Федак Дж., Чи Д., Хіберт К., Фетч Т., Маккаллум Б., Сюе А., Као В. Множинна стійкість до хвороб у міжродових гібридах

Похідні від чотирьох видів вторинного генофонду пшениці, а саме: один диплоїд (T. топососсит), два
\end{abstract} тетраплоїди (T. carthlicum; T. timopheevi) та один гексаплоїд (T. Migus chovae) були перевірені на стійкість до фузаріозу колосу, листової іржі, стеблової іржі та лінійної іржі. Після проведення скринінгу, генетичних досліджень та картографування пшениці було виявлено, що всі їі види мають множинну стійкість до хвороб. Деякі похідні лінії мають стійкість до чотирьох різних захворювань. Картування показало, що різні захворювання відображаються в різних хромосомах у межах одного приєднання.

Наше дослідження показує, що усі чотири генотипи мають стійкість до 4-5 різних захворювань. У більшості випадків фактори стійкості відображені в різних хромосомах. Множинна стійкість до хвороб стає досить поширеним явищем. Для прикладу: ми створили загалом тридцять штучних гексаплоїдів із використанням широкого спектра батьківських форм T. turgidum та T. tauschii. Стійкість до стеблової іржі, листової іржі, лінійної іржі та борошнистої роси була виявлена у різних генотипів, причому два генотипи мають стійкість до всіх чотирьох захворювань. Іншим прикладом нашого дослідження $є$ те, що дві комбінації часткових амфіплоїдів, отриманих із залученням T. turgidum i Th. intermedium $(2 \mathrm{n}=42$, геном формула ААВВЕЕ), мають стійкість до листкової іржі, стеблової іржі та фузаріозу колосу.

Наведені приклади взяті з досліджень у наших лабораторіях. Таке саме явище спостерігали і в інших лабораторіях світу.

Ці дослідження показують, що вторинні й третинні генофонди пшениці є чудовими джерелами мінливості для більшості хвороб. У своїх дослідженнях ми зазвичай зосереджуємося лише на одній хворобі. Завдання 3 наведених прикладів полягає в тому, що слід проводити скринінг стійкості до багатьох захворювань. Відкриття множинної стійкості до хвороб має зробити процес молекулярного картування ефективнішим.

Ключові слова: міжродові гібриди, пшениця, стійкість до хвороб, фузаріоз, листова іржа листя, стеблова іржа, борошниста роса.

Fedak G., Chi D., Hiebert C., Fetch T., McCallum B., Xue A., Cao W. Multiple disease resistance in intergeneric hybrids

Derivatives from four species from the secondary gene pool of wheat, one diploid (T. monococcum) two tetraploid (T. carthlicum; T. timopheevi) and one hexaploid (T. miguschovae), were screened for resistance to Fusarium head blight, leaf rust, stem rust, and stripe rust. Where screening, genetic studies and mapping has been completed it was shown that all species carry resistance to multiple plant diseases. Some derived lines carry resistance for up to 4 different diseases. Where mapping has been completed it was shown that different diseases map to different chromosomes within any one accession.

This study shows that of the four genotypes studied, all had resistance to 4-5 different diseases. In most cases the resistance factors mapped to different chromosomes. The multiple disease resistance is becoming a fairly common phenomenon. For example, we have produced a total of thirty synthetic hexaploids employing a wide variety of $T$. turgidum and T. tauschii parents. Resistance to stem rust, leaf rust, stripe rust, and mildew was detected in the various genotypes with two of them showing resistance to all four diseases. Another example from our laboratory is that of two combinations of partial amphiploids involving T. turgidum and Th. intermedium $(2 \mathrm{n}=42$, genome formula AABBEE) that had resistance to leaf rust, stem rust, and Fusarium head blight.

The above are examples taken from studies in our laboratories. The same phenomenon has been observed in other laboratories around the world.

These observations extend the principal that the secondary and tertiary genepools of wheat are excellent sources of variability for most diseases. In our studies we usually focus on one disease at a time. The lessons from the above examples are that screening for multiple diseases should be carried out. Discovery of multiple disease resistance should make the molecular mapping process more efficient.

Key words: intergeneric hybrids, wheat, disease resistance, fusarium, leaf rust, stem rust, mildew.

Introduction. The most important of diseases of wheat in all temperate wheat-growing regions of the world are the rusts caused by Puccinia triticina (leaf rust), $P$. striiformis (stripe rust), $P$. graminis 
(stem rust). More recently, Fusarium head blight, caused by Fusarium graminearum has become a serious disease. It not only causes yield reductions but also deposits a vomitoxin in the seed that is toxic to humans and other animals.

All four diseases are constantly mutating and recombining to create new races of each species of pathogen. This requires and endless supply of new resistance genes for each disease. There is not sufficient variability in the primary gene pool to keep up with the demand. There is abundant variability in the secondary and tertiary gene pool for all diseases. We have concentrated our efforts on recognizing variability for resistance to Fusarium head blight and introgressing the resistance into wheat.

\section{Materials and Methods \\ 1. Inoculation methods.}

For FHB evaluation, entire mapping populations were screened. Central florets of spikes at $50 \%$ anthesis were inoculated with $10 \mathrm{uL}$ of a 50,000 spores $/ \mathrm{mL}$ suspension of three virulent isolates of $F$. graminearum. Plants with inoculated spikes were placed in a mist chamber at $100 \%$ RH for 48 hours then returned to normal growth chamber conditions of $16 \mathrm{~h}$ light and day/night temperature regimes of $20 / 15^{\circ} \mathrm{C}$. At 21 days after inoculation, the symptoms were scored and expressed as percent infected florets.

For stem rust assays, the mapping populations plus check varieties were evaluated with stem rust race TTKSK. Ten plants of each DH progeny were assessed for seedling resistance at 14 days postinoculation using a 0-4 scale. Infection types from 0-2 + were considered resistant responses whereas those from 3-4 were considered to be susceptible responses.

For leaf rust resistance analysis, the DH lines and check varieties were grown as two sets of lines with three seeds per line, in flats in a greenhouse. They were inoculated with urediniospore suspensions in an oil carrier with isolates 12-3 MBDS and 06-1-1 TDBG (Long and Kolmer, 1989; McCallum et al., 2017). The inoculated flats were misted for $12 \mathrm{~h}$ and symptoms recorded at 14 days after inoculation. Ratings of $0, ;, 1$, and 2 indicated a resistant reaction whereas 3, 3+ indicated susceptible reactions. The origins of the four genotypes reported in this study are listed in Table 1 and procedures for introgression are detailed in the narrative.

\section{Plant materials}

Blackbird

Initial screening revealed Type II resistance to FHB. A DH mapping population was produced through wheat $\mathrm{x}$ maize pollination from an F1 hybrid between Blackbird and Strongfield.

M321

Production of M321 was initiated by the screening for FHB resistance of 260 accessions of $T$. monococcum obtained from M. Trottet of INRA.

A second cycle of screening identified FHB resistance in line 10-1. This was crossed and backcrossed once to AC Domain with concurrent screening to produce M321. A DH mapping population of 120 lines was produced from the hybrid M321 x Superb.

TC67

Accession PI 343447 of T. timopheevi was crossed to Crocus and 535 progeny advanced to BC1F7 by SSD. One hundred progeny were selected from this population, tested for resistance to $\mathrm{FHB}$ resulting in the selection of TC67 that showed a degree of resistance (Cao et al., 2009). TC67 was crossed to AC Brio to produce a mapping population of 230 lines.

\section{T. miguschovaae}

T. miguschovae is an amphiploid produced by the crossing of $T$. militinae (genome $\mathrm{A}^{\mathrm{b}} \mathrm{G}$ ) with $A e$. squarrosa (Zhirov, 1980). In our own screening we found that it also carried a degree of resistance to Fusarium head blight. The amphiploid was crossed to Superb and progeny advance to BC2F5 from which line MSB55-1 was selected .MSB55-1 was crossed to Superb and a mapping population of 137 doubled haploid lines was produced.

\section{Results \\ Blackbird}

The mapping population derived from Blackbird/Strongfield was phenotyped by point inoculation to detect Type II FHB resistance. Resistance QTL were mapped on chromosomes 2B and 6B (Somers et al., 2006) (Table 1). The latter was the same QTL as detected previously in hexaploid wheat whereas the $2 \mathrm{~B}$ QTL is unique. The same population was analyzed for Type I resistance and a QTL mapped on chromosome 1D (Singh et al., 2008).

In more detailed subsequent studies, using the 90K Infinium Select Chip as a marker system, FHB resistance QT: were detected on chromosomes 1A, $2 \mathrm{~A}, 3 \mathrm{~A}$ and $6 \mathrm{~B}$ with the one on chromosome $1 \mathrm{~A}$ being most consistent over environments (Sari et al., 2018). Loose smut resistance was mapped to chromosome 6B of Blackbird (Kumar et al., 2017, Table).

M321

The DH mapping population derived from M321 x Superb was phenotyped three times and after 
SSR mapping, a QTL was located on chromosome 5A linked to marker Xwmc 705 (Fedak et al., 2011). Subsequent mapping with SNP markers (Boyle et al., unpublished) revealed a FHB resistance QTL on chromosome $5 \mathrm{~A}$ and a leaf rust resistance QTL on chromosome 1B. The latter could be $S r 71$, so further testing is required to verify this fact.

TC67

The Tc67 $\mathrm{x}$ Brio mapping population was screened extensively for Type I, Type II FHB resistance, for Fusarium damaged kernels, and for DON content, As a result of this analysis, a major QTL was mapped on chromosome 5A that covered Type I and Type II resistance (Malihipour et al., 2015). A number of other minor QTL were detected for the other traits but since they were not significant were not reported.

Preliminary data indicate that TC67 also has resistance to stem rust and stripe rust.

M55-1 (T. miguschovae)

T. miguschovae, soon after its synthesis was found to carry resistance to leaf rust which was subsequently mapped to chromosomes 7B and 1D (Davoyan and Ternovska, 1996). It also has been reported to have resistance to stem rust, stripe rust, and mildew.

In our studies, the mapping population was screened for Type II FHB resistance and with the aid of SNP markers, QTL were mapped on chromosomes 2D and 5A.
Discussion. This study shows that of the four genotypes studied, all had resistance to 4-5 different diseases. In most cases the resistance factors mapped to different chromosomes. The multiple disease resistance is becoming a fairly common phenomenon. For example, we have produced a total of thirty synthetic hexaploids employing a wide variety of $T$. turgidum and T. tauschii parents. Resistance to stem rust, leaf rust, stripe rust, and mildew was detected in the various genotypes with two of them showing resistance to all four diseases. Another example from our laboratory is that of two combinations of partial amphiploids involving $T$. turgidum and $T$. intermedium $(2 \mathrm{n}=42$, genome formula AABBEE) that had resistance to leaf rust, stem rust, and Fusarium head blight. (Zeng et al, 2013).

The above are examples taken from studies in our laboratories. The same phenomenon has been observed in other laboratories around the world.

These observations extend the principal that the secondary and tertiary genepools of wheat are excellent sources of variability for most diseases. In our studies we usually focus on one disease at a time. The lessons from the above examples are that screening for multiple diseases should be carried out. Discovery of multiple disease resistance should make the molecular mapping process more efficient.

Table

Multiple Disease Resistance in Derivatives from Wide Crosses

\begin{tabular}{|c|c|c|c|c|}
\hline $\begin{array}{l}\text { Resistant } \\
\text { genotype }\end{array}$ & $\begin{array}{c}\text { Origin } \\
\text { (genome) }\end{array}$ & $\begin{array}{l}\text { Resistance } \\
\text { type }\end{array}$ & $\begin{array}{c}\text { Chromosome } \\
\text { location }\end{array}$ & Reference \\
\hline \multirow[t]{4}{*}{ "Blackbird" } & $\begin{array}{l}\text { T. carthlicum } \\
\text { (AABB) }\end{array}$ & FHB Type II & $6 \mathrm{~B}, 2 \mathrm{~B}$ & Somers et al., 2006 \\
\hline & & FHB Type I & $1 \mathrm{~A}$ & Singh et al., 2008 \\
\hline & & Leaf rust & $1 \mathrm{~A}, 2 \mathrm{~A}, 3 \mathrm{~A}, 6 \mathrm{~B}$ & Sari et al., 2018 \\
\hline & & Loose smut & $6 \mathrm{~B}$ & Kumar et al., 2017 \\
\hline \multirow[t]{3}{*}{ TC67 } & $\begin{array}{l}\text { T. timopheevi } \\
\text { (AAGG) }\end{array}$ & FHB Type I, II & $5 \mathrm{~A}$ & Malihipour et al., 2015 \\
\hline & & $\mathrm{Sr}$ & $3 \mathrm{~B}^{*}, 5 \mathrm{~A}$ & unpublished \\
\hline & & $\mathrm{Yr}$ & $1 \mathrm{~B}^{*}, 5 \mathrm{D}, 6 \mathrm{~B}$ & unpublished \\
\hline \multirow[t]{4}{*}{ M321 } & $\begin{array}{ll}T . & \text { monococcum } \\
\text { (AA) }\end{array}$ & FHB Type II & $5 \mathrm{~A}$ & Boyle et al. (pc) \\
\hline & & Leaf rust & $1 \mathrm{~B}^{*}, 5 \mathrm{D}, 6 \mathrm{~B}$ & Boyle et al. (pc) \\
\hline & & $\mathrm{Sr}$ & & preliminary \\
\hline & & mildew & & preliminary \\
\hline \multirow[t]{5}{*}{ M55-1 } & $\begin{array}{l}\text { T. miguschovae } \\
\text { (AAGGDD) }\end{array}$ & $\mathrm{Lr}$ & $7 \mathrm{~B}, 1 \mathrm{D}$ & Davoyan . Ternovska 1996 \\
\hline & & FHB & $2 \mathrm{D}, 5 \mathrm{~A}$ & unpublished \\
\hline & & $\mathrm{Yr}$ & & preliminary \\
\hline & & $\mathrm{Sr}$ & & preliminary \\
\hline & & mildew & & preliminary \\
\hline
\end{tabular}




\section{References}

1. Cao W., Fedak G., Armstrong K., Xue A., Savard M. E. 2009 Registration of spring wheat germplasm TC67 resistant to Fusarium head blight. Journal of Plant Registrations. 3: 104-106.

2. Davoyan R. D., Ternovska T. K. 1966 Use of a synthetic hexaploid Triticum miguschovae for transfer of leaf rust resistance to common wheat. Euphytica 89: 99-102.

3. Fedak G., Cao W., Chi D., Somers D., Miller S., Ouellet T., Xue A., Gilbert J., Savard M., Voldeng H. 2011. New sources of resistance to Fusarium head blight and their mode of action. In: Canty S., Clark A., Anderson-Scully A., Van Sanford D. (eds.) Proceedings of the 2011 National Fusarium head blight forum. East Lansing MI, p. 19-22.

4. Kumar S., Knox R. E., Singh A. K., DePauw R., Campbell H., Isidro-Sanchez J., Clarke F., Clarke J., Pozniak C. J., N'Daye A., Meyer B., Sharpe A., Ruan Y., Cuthbert R., Somers D., Fedak G., McCartney C. 2017. High density genetic mapping of a major QTL for resistance to multiple races of loose smut in durum wheat. PloS One, 13(2): e0192261. https://doi.org/10.1371/journal.pone.0192261.

5. Long D. L., Kolmer J. A. 1989. A North American system of nomenclature for Puccinia recondita f. sp Tritici. Phytopathology. 79: 525-529.

6. Malihipour A., Gilbert J., Fedak G., BruleBabel A., Cao W. 2015. Characterization of agronomic traits in a population of wheat derived from Triticum timopheevii and their association with fusarium head blight. European Journal of Plant Pathology. 144: 31-43.

7. McCallum B., Seto-Goh P., Xue A. 2017. Physiological specialization of Puccinia triticina, the causal agent of wheat leaf rust in Canada. Canadian Journal of Plant Pathology. 39: 454-463.

8. Sari E., Bervaies S., Knox R. E., Singh A. K., Ruan Y., Cuthbert R. D. et al., 2018.

9. Singh A. K., Knox R., Clarke F. R., Clarke J. M., Somers D. J., Fedak G., Singh A., DePauw R. 2008. Fusarium head blight QTL mapping in durum wheat and Triticum carthlicum sources of resistance. Proceedings of the $11^{\text {th }}$ International Wheat Genetics Symposium. Brisbane Australia.

10. Somers D., Fedak G., Clark J., Cao W. 2006. Mapping of FHB resistance QTL in tetraploid wheat. Genome. 49:1586-1593.

11. Zeng J., Cao W., Fedak G., Sun S., McCallum B. D., Fetch T. G., Xue A. G. 2013. Molecular cytological characterization of two novel durum - Thinopyrum intermedium partial amphiploid with resistance to leaf rust, stem rust, and Fusarium head blight. Hereditas. 150: 10-16.

12. Zhirov E. G. 1980. Synthesis of a new tetraploid wheat. Trudi Pro Prikladnoi Botanike, Genetica I Selektsiya. 68: 14-16. 